口特 集 $<$ 喉頭痏痕性病変へのアプローチ：治療への試み $>$

\title{
ステロイド声帯内注射
}

\author{
金沢 英哲
}

要 約: ステロイド声带内注射は, 㓔痕組織の軟化（stiffness の低下）と瘏痕容積の減量（粘 膜移動性の向上）を目的に施行している。反復すれば，侵襲から数十年経過した成熟期疟痕に も効果がある。一方, 本法単独で無痺痕治癒に導くことはなく, 厚く硬い㓔痕ではおのずと効 果の限界がある。声带疟痕治療の臨床は, 振動体たる声帯の物性再建のみでは不十分な症例も 多く, 声带の「可動性」,「三次元的な位置異常」,「緊張度」を考慮した集学的な治療を行う必 要がある，本法は最も簡便な治療法として有用である.

索引用語：声带㾮痕, 声帯内注射, トリアムシノロンアセトニド, 喉頭横隔膜症, 声門後部 癒着

\section{Intracordal Injection of Steroids: Triamcinolone Acetonide}

\author{
Hideaki Kanazawa
}

\begin{abstract}
The purpose of intracordal injection of steroids is to reduce scar volume and soften scar tissue. Repeated injections are also effective against scarring in the maturation phase. This therapy alone cannot induce scarless healing, however, and treatment should be multidisciplinary. This therapy is useful by virtue of its being the most convenient.
\end{abstract}

Key words: vocal fold scarring, intracordal injection, triamcinolone acetonide, laryngeal web, posterior glottic adhesion

\section{はじめに}

㓔痕とは, 各種侵襲により生じた組織欠損に対して, 肉芽組織の形成を経て最終的に緻密な膠原組織や結合 組織に置換され修復された状態をいう。皮膚痏痕で は，外見が平坦で掻痒感や関節拘縮がなければ，正常 の創傷治癒としてよい，肥厚性瘕痕，ケロイド，関節 拘縮をきたしたものが, 異常瘏痕として治療の対象と なる，審美目的で治療がなされることもある。声带痒 痕の問題は審美ではなく, (1)声带の物性変化, (2)声帯 の可動域制限，(3)気道狭窄，といった機能障害に尽き る，妊娠中期までの胎児では無瘀痕治癒する事実があ
るが ${ }^{1)}$, 妊娠後期以降の胎児および出生後のヒトでは 臨床的に無㓔痕治癒は達成されていない。つまり，将 来的に無㓔痕治癒を目指寸先進的医療研究とともに, 目前にいる患者の機能障害を少しでも軽快させ社会復 帰を目指す，という代償的アプローチを駆使すること が現状では不可欠である，ステロイドは，瘢痕組織を 減量・軟化させる効果が示されているものの ${ }^{2)}$ 単独で 無瘏痕治癒は達成できず, 後者の位置づけである。た だし，機能障害（声帯㾮痕）は完治せずとも軽減でき れば能力障害（音声障害）を克服する手助けとなりう るため，臨床的に使用する価值がある．

声帯瘏痕に見られる物性変化とは, 主に stiffness（硬

小山市民病院耳鼻咽喉科：=323-0028 栃木県小山市若木町 1-1-5

Department of Otorhinolaryngology, Oyama Municipal Hospital: 1-1-5 Wakagi-cho, Oyama, Tochigi 323-0028, Japan 2010 年 2 月 12 日受理 
さ）の増大と声帯粘膜移動性の低下を指す，粘膜固有 層浅層に限局する微小声带病変でも, 声帯振動が障害 されれば音声障害をきたす。声带痏痕は，粘膜固有層 に限局する病変とは限らず，筋層に及ぶものも当然あ る。粘膜固有層浅層までに限局する微小病変であれば 声带可動域制限や気道狭窄といった問題がないため比 較的治療対象としやすく, 種々の治療法が実践されて いる。 しかし，㓔痕が深層に及ぶほど対応に難渋する ことは想像に難くない，瘏痕がどの層まで及ぶのか治 療前に正確な評価をすることは困難であり，この点も 治療方針の考慮にあたり課題となっている。

声帯の可動域制限には, 骨折や喉頭截開術後の喉 頭枠組み変形, 輪状披裂関節固着, 輪状甲状関節離 断, 喉頭横隔膜症, 声門後部癒着, などが挙げられる. 3D-CT で病態を把握できる症例がある

気道狭窄は, 粗大な声带 (喉頭) 痏痕にしばしば認 められ，治療のゴールが気道確保にとどまらざるをえ ない難症例が散見される.

\section{声帯㓔痕性病変へのアプローチ}

諸家の報告から，(1)切除，(2)置換，(3)ステロイド声 带内注射, (4)喉頭枠組み手術, (5)気道確保, (6)再生, といったアプローチがなされている、いずれも, 単独 の手法で確立された治療法はない，まず必要があれば (5)気道確保が最優先であり，そのうえで少しでも音声 改善を図るために，筆者らは主に(2)（声带粘膜移植

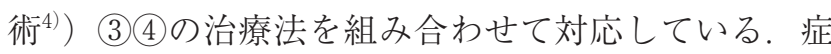
例を提示する。このうち, 最も簡便である(3)ステロイ ド声帯内注射は, (2)(4)の治療前後に反復して使用して いる.

症例 1:45 歳, 男性（図 1)

現病歴：14歳のとき交通外傷受傷時から嗄声が出 現して以降不変, 他院で片側喉頭麻瘏と診断されてい た. 45 歳になり音声改善を希望し受診, 左声門後部 癒着を認めた。発声時は両仮声帯が過閉鎖するため声 門レベルの評価は不能であり, 粗粘性嗄声を呈した. トリアムシノロンアセトニド（Tr-A）を瘏痕組織内 に計 4 回局注したところ, 自覚的な音声改善が得られ, 他覚的には左声門後部の痏痕部位の撓み方が変化して いた，痏痕が柔らかくなり声帯可動性が向上したと考 えられる。

症例 2:74 歳, 男性（図 2)

現病歴：61歳のとき他院で声門癌 $\mathrm{T} 2$ と診断され化 学放射線治療を受けた. 70 歳と 71 歳のとき局所再発 ありそれぞれ切除術を施行されたが，術後徐々に発声

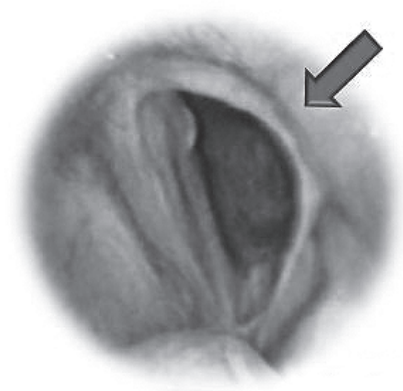

治療前

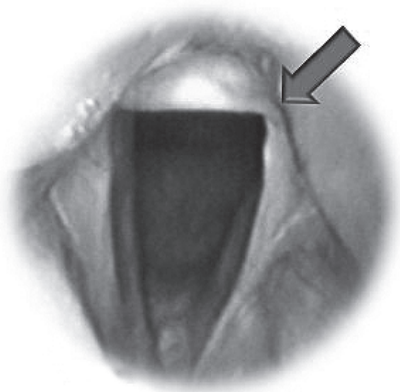

治療後

\begin{tabular}{|lrlc|}
\hline 間隔(日) & 麻酔, 手技 & 左 $(\mathrm{ml})$ \\
\hline (1) & & 局麻, 経皮 & 1.0 \\
& 29 & 全麻, 経口 & 1.0 \\
(2) & 223 & 局麻, 経皮 & 1.5 \\
(3) & & 局 \\
(4) & 137 & 局麻, 経皮 & 2.0 \\
\hline
\end{tabular}

図 1 症例 1 : 左声門後部癒着

左：治療前.

中：計 4 回のステロイド声帯内注射の施行間隔, 施行方法, 注射量を示す.

右：治療後.声帯の撓みが変化している.

困難となり，74歳のとき受診，前連合癒着を認めた。 㓔痕切除術の前後に, 複数回 Tr-A を㾮痕組織内に局 注し，経過観察した，再癒着傾向はなく，さらなる音 声改善のため喉頭截開して, 口唇粘膜による声帯粘膜 移植術 ${ }^{4}$ を施行した。術後移植粘膜が振動体として機 能し, 発声が可能となった。 ステロイド声帯内注射単 独の治療効果判定はできないが，このように集学的治 療アプローチの一翼を担っている.

\section{創傷治癒におけるステロイド作用}

一般に創傷治癒過程は, 侵襲後の生体反応として, 血管反応期，炎症期，増殖期，成熟期の分類が提唱さ れている5 . それぞれの期に打けるステロイド作用に ついて述べる，血管反応期では，増殖因子濃度を減少 させ, 炎症反応を抑制する。炎症期では, マクロファー ジ機能を低下させ，炎症反応を抑制する，増殖期では， コラーゲン生合成を低下させ, 瘏痕容積の減量を期待 できる。成熟期（侵襲後約 21 日〜 1 年以上）では, コラーゲンの抗張力発現に必要とされる架橋構造が行 われている。この反応に必要な水酸化酵素はステロイ ドにより抑制され，コラーゲンの肥厚・抗張力を減弱, 軟化させる ${ }^{6)}$. 声带瘏痕は視診上捉えにくく, 治療介 入が敬遠される，または治療介入によりさらに複雑化 したものなど，初期侵襲から数十年経過した症例も少 

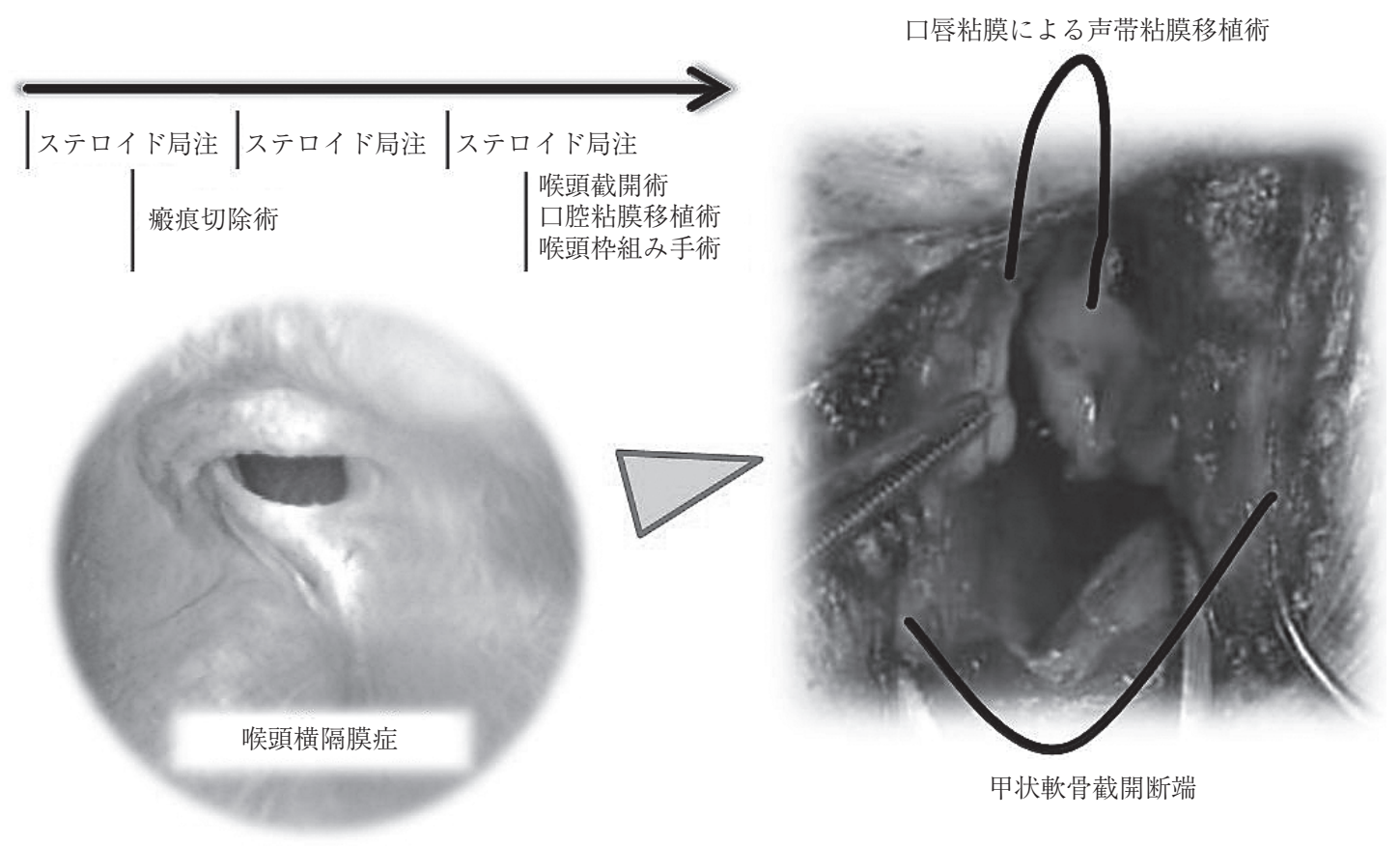

図 2 症例 2 : 前連合癒着

左上：治療経過概略. ステロイド声帯内注射は手技が簡便であるため, 瘢痕切除や喉頭形成術を施行する間, 随時施行できる。

左下：初診時喉頭所見.

右：喉頭截開し，口唇粘膜による声帯粘膜移植術施行時の術中所見.

なくない. 症例 1 は受傷から 31 年が経過していたが, この状況においてもステロイド声带内注射により㓔痕 の軟化によって声带可動性が向上し, 音声改善が得ら れた，単回治療のみでも自覚的な改善を得られること はあるが，通常は反復注射を要するものと認識してお く必要があり，厚く硬い痏痕であれば短期的成果は期 待しにくい.

\section{トリアムシノロンアセトニド（Tr-A）}

筆者らは，もっぱらトリアムシノロンアセトニド （Tr-A）を使用している。Tr-A は 1961 年に発売され た水性懸濁注射液であり，局注すると薬郕は局所にと どまることで約 21 日間効果が持続する77. Tr-Aのも つ抗炎症作用は, プレドニゾロンの約 10 倍とされる ${ }^{8)}$. Tr-A は，ケロイドに対して局所注射を反復すれば確 実に柔らかく平坦化する治療法として報告され ${ }^{9)}$, 確 立された治療法の一つとなっている。喉頭領域におい ては，柳原らは肥厚性喉頭炎を含む慢性炎症性喉頭疾 患の治療に水性懸濁プレドニン声帯内注射10) や水性 デキサメサゾン声帯内注射11) を行い，高い治療効果 を報告している。平野ら ${ }^{12)}$ は水性べタメタゾン声带 内注射で検討を行い，声帯ポリープや声帯結節といっ
た炎症性疾患には著効したが，喉頭外傷後の慢性喉頭 炎では一過性の軽快にとどまり，声带癌でコバルト 60 照射後症例に同剂声带内注射した（2 回施行）結 果は無効で，これらはステロイド療法の限界を示すも のと述べた。 Bouchayer ら ${ }^{13)}$ は，喉頭微細手術時の 術後㓔痕予防としてのステロイド薬の使用を報告して いる．Tr-A は，これらの薬荗より長期に薬理作用が 発揮されるため, さらなる効果が期待される.

$\operatorname{Tr}-\mathrm{A}$ 局注の副作用は，注射部位の皮膚障害（座瘡 など），内分泌障害（満月様顔貌など），女性生殖器系 障害（月経異常など），適用部位障害（皮膚・筋萎縮 など）が報告されている ${ }^{14)}$. 自験例でも，上記の副作 用はときに認められたが，いずれも中止により自然軽 快し，重篤な副作用は経験していない，Tr-Aケロイ ド内局注後の血清コルチゾール值の変動と回復期間を 見た検討 ${ }^{15)}$ では, $20 \mathrm{mg}$ ではほぼ 3 週目に, $40 \mathrm{mg}$ 局 注では 5 週目に血清コルチゾール值は施行前のレベル に復する。筆者は，1 回に 10〜30 mg を使用し，最 短治療間隔は 4 週間としている.

Tr-A 製剤は冷所で凝集する性質があり，これを関 節腔に局注すると結晶誘発性滑膜炎により疼痛腫脹を きたす現象が報告されている ${ }^{14,16)}$ 。喉頭領域において 
は涉猟する限りこの合併症の報告はないが，起きれば 気道リスクともなりかねないため, 貯法は室温保存を 厳守せねばならない。

Tr-A 声帯内注射後 3〜4 日までは, 声帯は薬液の容 積で浮腫状に腫脹し，失声となる。施行後約 7 日目ま でに，液性成分が吸収されて施行前の音声に復する。 これまでの期間，薬液が注射部位に安定してとどまる よう発声を極力控えることが望ましいことを，患者に 指導する。

\section{まとめ}

・ステロイド声帯内注射は, 躲痕組織の軟化 (stiffness の低下) と㓔痕容積の減量（粘膜移動性の 向上）を目的に行う.

・手技は簡便で，反復施行すれば成熟期㓔痕にも効 果がある。

·本法単独で無瘏痕治癒に導くことはなく, 厚く硬 い疲痕では効果の限界がある。

\section{文献}

1) Dang C, et al: Fetal wound healing: current perspectives. Clin Plast Surg, 30: 13-23, 2003.

2) Anstead G: Steroids, retinoids, and wound healing. Adv Wound Care, 11: 277-285, 1998.

3) 桜井一生: 3 次元画像診断の実際: 喉頭 -気管領域の 3 次 元画像診断 喉頭外傷. JOHNS, 22: 1296-1302, 2006.

4) Isshiki N: Surgical management of scar of the vocal cord. Phonosurgery, Springer-Verlag Tokyo, Tokyo, pp 175178, 1989 .

5) Wound Healing (edited by Cohen I, et al), WB Saunders, Philadelphia, 1992.
6）渡辺 皓, 菊地憲明, 館 正弘監訳：創傷治癒の生理学. 創傷治癒の必須知識, エルゼビア・ジャパン, 東京, 81 117 頁, 2008 .

7）草間光俊，他：Triamcinolone acetonide 筋注後の血中濃 度及び尿中排泄率に関する研究. 日内分泌会誌，46：654658, 1980.

8) McKenzie AW: Method for comparing percutaneous absorbtion of steroid. Arch Derm, 86: 608-611, 1962.

9) Hollander A: Intralesional injection of triamcinolone acetonide: a therapy for dermatoses. Antibiotic Med Clin Ther, 8: 78-83, 1961.

10）柳原尚明，林律，須藤淳子，他：副腎皮質ホルモン剂 (プレドニン)による慢性炎症性喉頭疾患の治療. 耳鼻臨床, $56: 16-20,1963$.

11）柳原尚明, 東 文生, 小池靖夫, 他：副腎皮質ホルモン剂 デキサメサゾン（デカドロン）の声帯内注射療法。耳鼻臨 床, $57: 38-42$, 1964.

12）平野 実, 進武 幹, 古川 満, 他：喉頭の炎症性疾患 に対する喉頭内リンデロン局所注射について。耳鼻, 11 ： 118-123, 1965.

13) Bouchayer M and Cornut G: Microsurgery for benign lesions of the vocal folds. Ear Nose Troat J, 67: 446-466, 1988.

14）医薬品インタビューフォーム．日本標準商品分類番号 872454, 2009.

15）青山 久, 井沢洋平：ケロイドに対するトリアムシノロン 局注の血清コーチゾール值への影響. 日形会誌，2:847851, 1982

16）鳥巣岳彦：ステロイド関節内注射（解説）、日本医事新報, 4109:1-5, 2003.

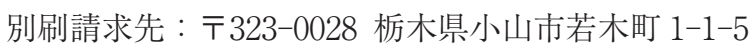
小山市民病院耳鼻咽喉科 金沢英哲 